\title{
The equilibrium flow and mass balance of the Taku Glacier, Alaska 1950-2006
}

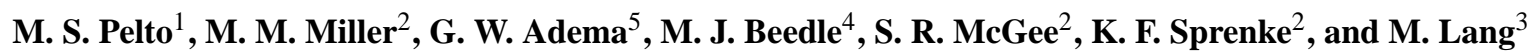 \\ ${ }^{1}$ Nichols College Dudley, MA 01571, USA \\ ${ }^{2}$ Glaciological and Arctic Sciences Institute, University of Idaho, Moscow ID 83843, USA \\ ${ }^{3}$ Institute of Geodesy, Universitat der Bundeswehr, Werner Heisenberg Weg, 85577 Neubiberg, Germany \\ ${ }^{4}$ Geography Program, University of Northern British Columbia, 3333 University Way, Prince George, B.C. V2L 2R4, Canada \\ ${ }^{5}$ Denali National Park and Preserve, P.O. Box 9, Denali Park, AK 99755, USA
}

Received: 11 March 2008 - Published in The Cryosphere Discuss.: 5 May 2008

Revised: 1 September 2008 - Accepted: 26 September 2008 - Published: 13 November 2008

\begin{abstract}
The Taku Glacier, Alaska has advanced $7.5 \mathrm{~km}$ since the late nineteenth century, while all other primary outlet glaciers of the Juneau Icefield are in retreat. The Juneau Icefield Research Program has completed field work on the Taku Glacier annually since 1946 . The collected observations of surface mass balance, glacier velocity and glacier thickness at Profile IV $29 \mathrm{~km}$ above the terminus and $4 \mathrm{~km}$ above the equilibrium line provide a means to assess the equilibrium nature of the Taku Glacier. Annual velocity measured and summer velocity measurements completed at a Profile IV from 1950-2006 indicate insignificant variations in velocity seasonally or from year to year. The consistency of velocity over the 56-year period indicates that in the vicinity of the equilibrium line, the flow of the Taku Glacier has been in an equilibrium state.

Surface mass balance was positive from 1946-1988 averaging $+0.42 \mathrm{~m} \mathrm{a}^{-1}$. This led to glacier thickening. From 1988-2006 an important change has occurred and annual balance has been $-0.14 \mathrm{~m} \mathrm{a}^{-1}$, and the glacier thickness has ceased increasing along Profile IV.

Field measurements of ice depth and surface velocity allow calculation of the volume flux at Profile IV. Volume flux is then compared with the surface balance flux from the region of the glacier above Profile IV, determined annually in the field. Above Profile IV the observed mean surface flux from 1950-2006 is $5.50 \times 10^{8} \mathrm{~m}^{3} \mathrm{a}^{-1}( \pm 5 \%)$, while the calculated volume flux range for the same period flowing through profile IV is $5.00-5.47 \times 10^{8} \mathrm{~m}^{3} \mathrm{a}^{-1}$. The mean sur-
\end{abstract}

Correspondence to: M. S. Pelto

(mspelto@ nichols.edu) face flux has been greater than the volume flux, which has led to slow thickening of the Taku Glacier up to 1988. The thickening has not led to a change in the flow of Taku Glacier at Profile IV.

\section{Introduction}

Taku Glacier is a temperate, maritime valley glacier in the Coast Mountains of Alaska. With an area of $671 \mathrm{~km}^{2}$, it is the principal outlet glacier of the Juneau Icefield (Fig. 1) $\left(58.625^{\circ} \mathrm{N}\right.$ and $\left.134.25^{\circ} \mathrm{W}\right)$. It attracts special attention because of its continuing, century-long advance (Pelto and Miller, 1990; Post and Motyka, 1995), while all other outlet glaciers of the Juneau Icefield are retreating. Taku Glacier is also noteworthy for its positive mass balance from 1946-1988 (Pelto and Miller, 1990), during a period when alpine glacier mass balances have been dominantly negative (Dyugerov and Meier, 1997). Finally, it is unique as the thickest alpine glacier yet measured, with a fjord extending 38-48 km upglacier from its terminus (Nolan et al., 1995).

The Juneau Icefield Research Program (JIRP) has completed field work on the Taku Glacier annually since 1946 (Miller, 1963; Pelto and Miller, 1990). In this paper we present a data set for the Taku Glacier that is unique in its temporal extent containing:

1) Surface velocity data Profile IV, spanning 56 years, a single transverse profile prior to 1993 at the location of the lower line and two parallel transverse profiles, separated by $0.24 \mathrm{~km}$ since 1993 (Fig. 2); 2) Seismic profiling depth data along Profile IV; 3) Centerline longitudinal velocity transects from the glacier divide to slightly below the ELA in

Published by Copernicus Publications on behalf of the European Geosciences Union. 


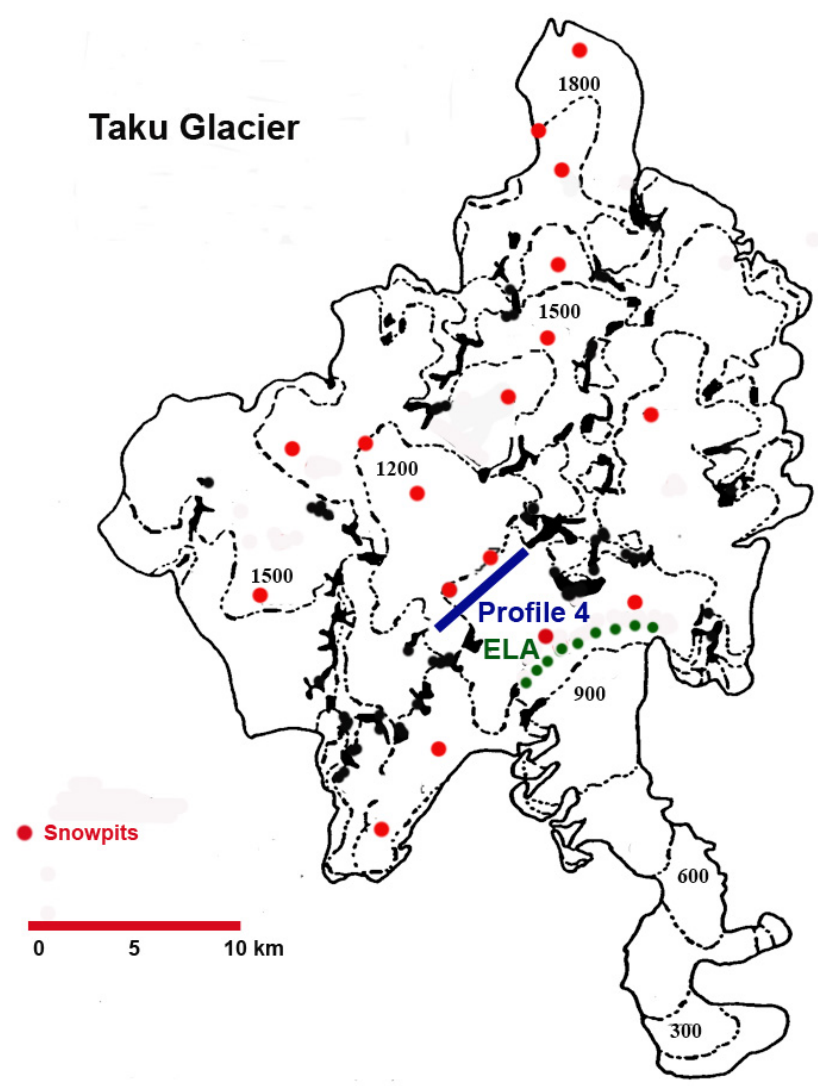

Fig. 1. Location map for Taku Glacier, indicating Profile IV, snowpit locations and the ELA, (North to top).

the ablation zone; and 4) Surface mass balance data from 1946-2006. From this data we determine surface balance and volume balance transfers. This provides a field-based quantitative determination of the volume flux at multiple locations.

Taku Glacier is divided into three zones that describes both mass balance and flow dynamics: (1) The ablation zone, below the mean annual ELA of $925 \mathrm{~m}\left(113 \mathrm{~km}^{2}\right)$, descends the trunk valley with no tributaries joining the glacier, and only the distributary tongue, Hole in the Wall, leaving the glacier $9 \mathrm{~km}$ above the terminus. (2) The lower neve zone, extending from the ELA at $925 \mathrm{~m}$ to $1350 \mathrm{~m}$, is a zone where summer ablation is significant $\left(178 \mathrm{~km}^{2}\right)$. All the main tributaries (Southwest, West, Matthes, Demorest, and Hades Highway) join in this zone. Profile IV is in this zone, and comprises the flow of the Matthes and West Branch. (3) The upper neve zone extends from $1350 \mathrm{~m}$ to the head of the glacier $\left(380 \mathrm{~km}^{2}\right)$, comprising the principal accumulation region for each tributary except the Southwest Branch. Ablation is limited in this zone, with much of the summer meltwater refreezing within the firnpack. This refreezing results in a unique signature in SAR imagery (Ramage et al., 2000).

Taku Glacier has been advancing since 1890: It advanced $5.3 \mathrm{~km}$ between 1890 and 1948 (Post and Motyka, 1995; Pelto and Miller, 1990). The glacier advanced $1.8 \mathrm{~km}$ from

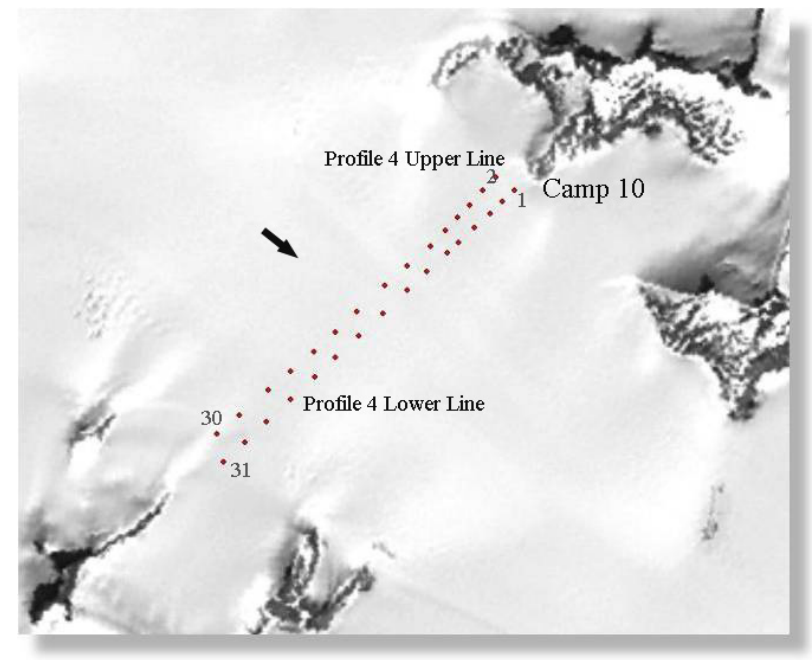

Fig. 2. Position of marker flags on Profile IV, for the upper and lower line. Flow direction noted by arrow. Base Station is on the nunatak at Camp 10. Selected flag numbers listed.

1948-1988 (Post and Motyka, 1995), and $0.4 \mathrm{~km}$ from 1988 to 2003. The advance rate measured by distance is slowing. The rate of advance is best assessed in terms of area as the terminus lobe is spreading out on a terminus shoal. Motyka and Post (1995) noted that the rate from 19481963 was $0.428 \mathrm{~km}^{2} \mathrm{a}^{-1}, 0.345 \mathrm{~km}^{2} \mathrm{a}^{-1}$ from $1963-1979$ and $0.11 \mathrm{~km}^{2} \mathrm{a}^{-1}$ from $1979-1988$. The slowing of the advance has been attributed to the impedance of the terminus outwash plain shoal (Motyka and Post, 1995), but it has also been conjectured as due to the inability of the mass balance to sustain this advance. With an AAR of 0.82, Taku Glacier had a continuously positive mass balance from 1946-1994, that has driven the continued advance (Pelto and Miller, 1990). This high a value for AAR is not unusual for an Alaskan glacier in the advance phase of the tidewater glacier cycle, Hubbard Glacier is another example (Pelto and Miller, 1990). Pelto and Miller (1990) postulated that the positive mass balance from 1946-1985, and high AAR would drive the continued advance until the end of the century regardless of mass balance in the ensuing years. From 1988-2006 mass balance has been slightly negative, however the glacier has continued to advance as expected by Pelto and Miller (1990) and Motyka and Beget (1996).

\section{Data collection}

\subsection{Surface mass balance}

JIRP has measured the annual balance of the Taku Glacier from 1946 to 2006 (Pelto and Miller, 1990). Glacier annual mass balance is the difference between the net snow accumulation and net ablation over one hydrologic year. On non-calving glaciers, such as the present Taku Glacier, 
surface mass balance observations are used to identify changes in glacier volume. JIRP has relied on applying consistent methods at standard measurement sites (Pelto and Miller, 1990; Miller and Pelto, 1999). On the Taku Glacier 17 test pits at fixed sites (Fig. 1) ranging from $950 \mathrm{~m}$ to $1800 \mathrm{~m}$ are completed directly measuring the snow water equivalent (SWE), the migration of the transient snow line is monitored, ablation during the field season along survey lines and the final ELA position at the end of the balance year is located (Pelto and Miller, 1990). Six of the snowpits are near the ELA from 950-1200 m, six are from 1200-1400 m and five snowpits are from 1400-1800 m annually. Compared with Gulkana Glacier $\left(19 \mathrm{~km}^{2}\right)$ and Wolverine Glacier $\left(18 \mathrm{~km}^{2}\right)$ where the USGS annually assesses glacier mass balance from 3 measurement sites, the number of measurements on Taku Glacier is large (Mayo et al., 2004; March and Trabant, 1996). The size of the Taku Glacier is more than an order of magnitude larger leading to a lower density of measurements. The distribution of annual measurements on Taku Glacier is skewed toward the ELA and non-existent in the ablation zone. On Gulkana Glacier there is one site in the ablation zone, and two sites near the ELA, and no sites in the upper $600 \mathrm{~m}$ of the glacier (March and Trabant, 1996). On Wolverine Glacier there is one site in the ablation zone, one site at the ELA and one in the accumulation zone (Mayo et al., 2004). The point being, extrapolations of mass balance from observations sites are typical and a consistent source of error in Alaskan glacier mass balance assessment (Miller and Pelto, 1999). The advantage on Taku Glacier is that there are multiple measurements sites at each elevation providing a more robust basis for annual extrapolation of mass balance change with elevation, the disadvantage is the areal extent is larger over which the extrapolations are made.

The shift in position of the ELA is a particularly useful measure of ablation. For example in 2004 the ELA rose from $800 \mathrm{~m}$ on $12 \mathrm{July}$, to $980 \mathrm{~m}$ on 16 August and $1040 \mathrm{~m}$ on 12 September. Measurement of snow depth at twelve locations between $960 \mathrm{~m}$ and $1000 \mathrm{~m}$ in mid-July indicated snow depths of $1.1 \mathrm{~m}$, and at 12 locations from $1020 \mathrm{~m}$ to $1060 \mathrm{~m}$ of $1.55 \mathrm{~m}$. This identified the ablation rate for the period from mid-July to mid-September and allowed adjustment of test pit measurements.

To address the error resulting from extrapolations in 1984, 1998 and 2004, JIRP measured the mass balance at an additional 100-500 points with probing transects in the accumulation area to better determine the distribution of accumulation around the test pit locations. Measurements were taken along profiles at 100-250 m intervals. The standard deviation for measurements sites within $3 \mathrm{~km}$, with less than a $100 \mathrm{~m}$ elevation change, was $\pm 0.09 \mathrm{~m}$ w.e. (water equivalent); this indicates the consistency of mass balance around the test pit sites. Another possible source of error is the assumption that the density measured at test pits is representative of a larger area. However, a study at 40 points within $1 \mathrm{~km}^{2}$ at different elevations in different years resulted in a standard deviation of $\pm 0.07 \mathrm{~m}$ w.e. in a snow pack of 1 to $2 \mathrm{~m}$, displaying the highly uniform density of snow on the Taku Glacier in late summer (Pelto and Miller, 1990).

The measurements of retained accumulation are completed during late July and August and are adjusted to end of the balance year values. This is done via daily ablation rates derived through annual stake ablation measurements and migration of the transient snow line (Pelto and Miller, 1990; Miller and Pelto, 1999). The ELA is observed each year in photographs and/or Landsat imagery of the Taku Glacier taken in early September. The ELA may rise slightly after that date, but snowfall is already a consistent event by early September in the ELA region.

In the ablation zone, the mass balance curve is adjusted based on the ELA and on measurements of ablation in nine different years from 1950-1997. The resulting ablation peaks at $12 \mathrm{~m}$ at the terminus (Pelto and Miller, 1990). Independent examination of ablation at the terminus R. Motyka, personal communication, 2004), has identified ablation rates at the terminus of 12-14 m during two slightly warmer than usual ablation seasons 2003 and 2004.

Possible errors for the Taku Glacier mass balance record include the sparse density of measurement points (1 per $37 \mathrm{~km}^{2}$ ), extrapolation to the end of the balance year, infrequent measurements of melting in the ablation zone, and measurements carried out by many different investigators. However, Pelto and Miller (1990), suggest that these sources of error are mitigated by annual measurements at 17 fixed locations, using nine years of ablation data to extrapolate mass balance in the ablation zone, using an annual balance gradient derived from the 17 fixed sites and known values for the ablation zone that shifts in altitude from year to year based on the ELA, and through supervision of field work by at least one experienced researcher. JIRP has utilized the same methods on the Lemon Creek Glacier where independent long term radar surface profiling has indicated the accuracy of the record (Miller and Pelto, 1999). The principal error is the lack of data from the ablation zone. In this paper we are reporting the mass balance for the entire glacier but utilizing data only from the accumulation zone above Profile IV for the surface flux calculation.

How accurate is the mass balance record? The long term record is compared with the change in ice thickness using repeat laser altimetry data and a comparison of this data with the 1948 based USGS maps (Arendt, 2006; Arendt et al., 2002; Larsen et al., 2007). This was accomplished from a centerline profile providing a whole glacier determination. Surface elevation change is not strictly a measure of mass balance, though it is reported as such (Arendt, 2006). The observed change in Taku Glacier surface elevation was $0.69 \mathrm{ma}^{-1}$ from 1948-1993 and $-0.28 \mathrm{ma}^{-1}$ from 1993-1997 (Arendt, 2006). The mass balance for these periods from field observations is $0.38 \mathrm{ma}^{-1}$ for $1948-1993$ and $-0.60 \mathrm{ma}^{-1}$ for $1993-1997$. The surface record includes the very negative mass balance of 1997 , while the laser altimetry 
does not include this full ablation season of 1997, $-1.34 \mathrm{~m}$ w.e. The long term observed ice surface elevation changes validate the relative accuracy of the mass balance record of the Taku Glacier.

A second independent measure of mass balance is now available in the form of direct measurement of the surface elevation of the glacier at specific points. The elevation has been determined annually since 1993 at fixed locations along Profile IV using differential GPS as part of the velocity surveying program. GPS annual elevation change measurements along Profile IV at $1100 \mathrm{~m}$ show a strong correlation with annual mass balance measurements. This would be expected as elevation at the mean ELA is likely to rise with increased accumulation during years of positive mass balance, and fall with increased ablation during years of negative mass balance. Glacier dynamics also affect surface elevation, as the glacier can have either an emergent of submergent component to velocity. In the vicinity of the ELA as is the case at Profile IV this factor is minimized. Further the stable velocity indicates that there has not been a change in glacier dynamics that would alter the emergent velocity.

Many glaciers with long mass balance records lack data to corroborate the long term changes observed. Taku Glacier has this independent record. The mass balance record is consistently determined and hence is precise if not accurate.

\subsection{GPS survey methods}

A key objective of the JIRP surveying program is to collect data that allows quantitative comparison of surface movements and surface elevation change from year to year.

All geodetic observations from 1993-2006 on the icefield are made using a differential GPS method. Profile measurements were determined using the real time kinematic GPS technique, which involved sending a correction signal from the reference station to a mobile rover unit in real time. All JIRP surveying utilizes survey-grade, dual-frequency, realtime kinematic GPS systems including the Leica System 300, Leica System 530, and Trimble 5700 units.

Since 1993 Profile IV has been established each year with the same number of survey flags, flag spacing, and flag location. It consists of 31 flags arranged in two parallel transects, placed approximately $240 \mathrm{~m}$ apart, which are offset to form a series of 29 triangles between the 16 flags on the down glacier transect and the 15 flags on the up glacier transect. All surveys since 1993 have utilized this arrangement, which allows for the computation of strain rates, height change, and velocity. Standard stake-out coordinates specify the exact easting and northing positions for each flag and are loaded into the roving GPS unit and the operator navigates to within $0.5 \mathrm{~m}$ of the flag coordinates. A roving receiver is mounted on an aluminum monopole inserted into the same hole that the survey flag is placed. The height above the snow surface of the antenna is noted. The position is then recorded and a survey flag is placed into the snow in the same location where the rover's range pole was positioned for the measurement. A second survey is done 5 to 10 days later. The coordinates of the first and second surveys are then analyzed to determine the surface velocity and direction of movement. For all surveys, the reference receiver is centered and leveled over a bedrock benchmark at Camp 10, adjacent to Profile IV (Fig. 2).

The major focus of the survey program is to continue the annual survey of standard movement profiles on the Taku Glacier and its main tributaries. A major component of this effort is the annual survey of a longitudinal profile down the centerline of the Matthes Branch and the Taku Glacier, from the glacier divide (located $58 \mathrm{~km}$ from the terminus), downglacier to $12 \mathrm{~km}$ above the terminus. The surface velocity and surface slope are observed at survey locations spaced $0.5 \mathrm{~km}$ apart. The longitudinal profile has been surveyed annually since 1999 .

\subsection{Seismic methods}

Seismic methods are required to determine ice depths on transverse profiles because of the thickness of the Taku Glacier (Nolan et al., 1995). The seismic program completed measurements of ice thickness along eight transects across the glacier, each following the same transects and using the same points used in the GPS movement and elevation surveys.

The seismic methods used for determining ice thickness are typical. A Bison 9024 series seismograph was used with 24 high-frequency $(100 \mathrm{~Hz})$ geophones to record the seismic signals produced by explosive charges. The geophones were spaced at $30 \mathrm{~m}$ intervals along profile lines that are perpendicular to the direction of glacier flow, covering $690 \mathrm{~m}$ with each geophone spread. Explosive detonations (shots) were generally made at $500 \mathrm{~m}$ intervals from each end of the geophone spread, to a maximum distance of $2000 \mathrm{~m}$. Shot and geophone locations were surveyed using standard differential GPS surveying techniques, accurate to $\pm 5 \mathrm{~cm}$. Up to twelve shots were taken on each profile, with up to four reflectors evident on each shot's record. The seismograph was normally set to record two seconds of data, recording at a $0.25 \mathrm{~ms}$ sampling rate. The energy for a shot was produced by 4 to 20 sticks of Kinepak ( $1 / 3$ stick) explosive (ammonium nitrate and petroleum distillate combination), buried approximately $1 \mathrm{~m}$ deep in the firn.

Reflections from the glacier bed were generally clear and easy to recognize on the records by their frequency, character, and distinct moveout times. Migrations were completed using the common-depth-point technique described in Dobrin (1960) and adapted by Sprenke et al. (1997). Calculations were made using a constant ice velocity of $3660 \mathrm{~m} / \mathrm{s}$, a value determined from $\mathrm{P}$-wave first arrival times. The migration and geomorphic profiling process is based on the simplifying assumption that the glacier cross-sections are twodimensional. 


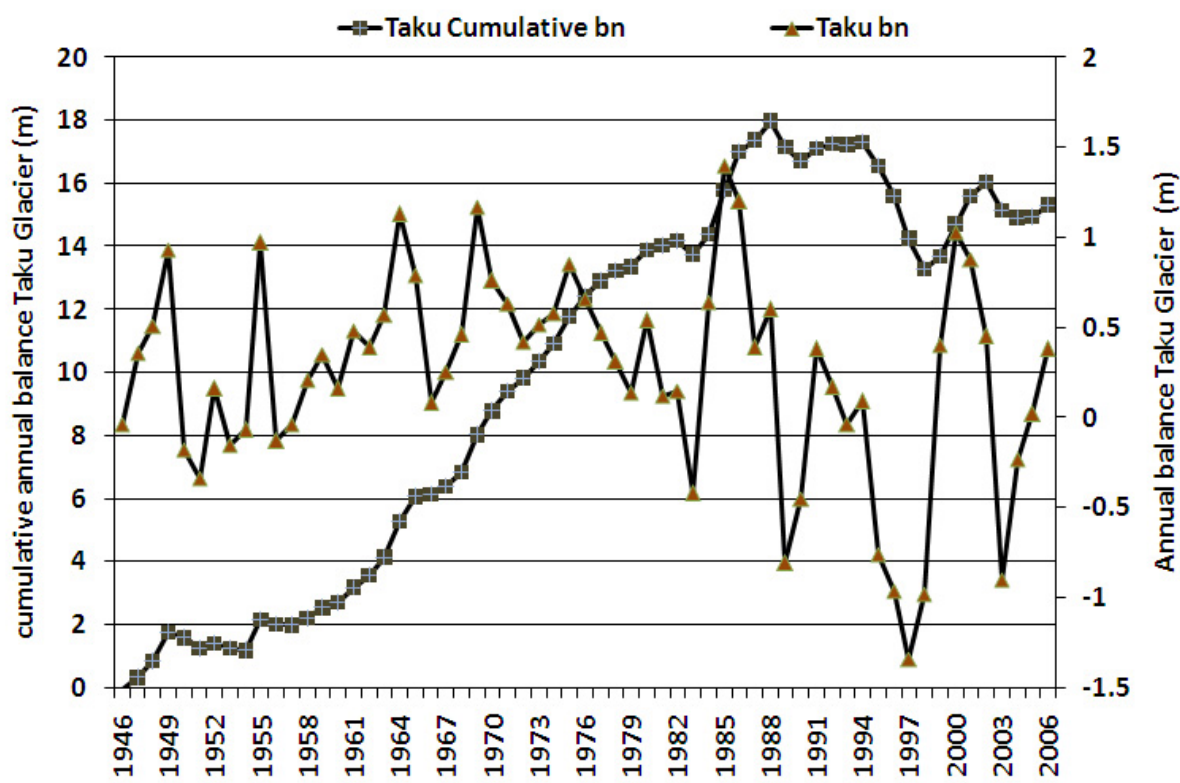

Fig. 3. Annual and cumulative balance of Taku Glacier 1946-2006.

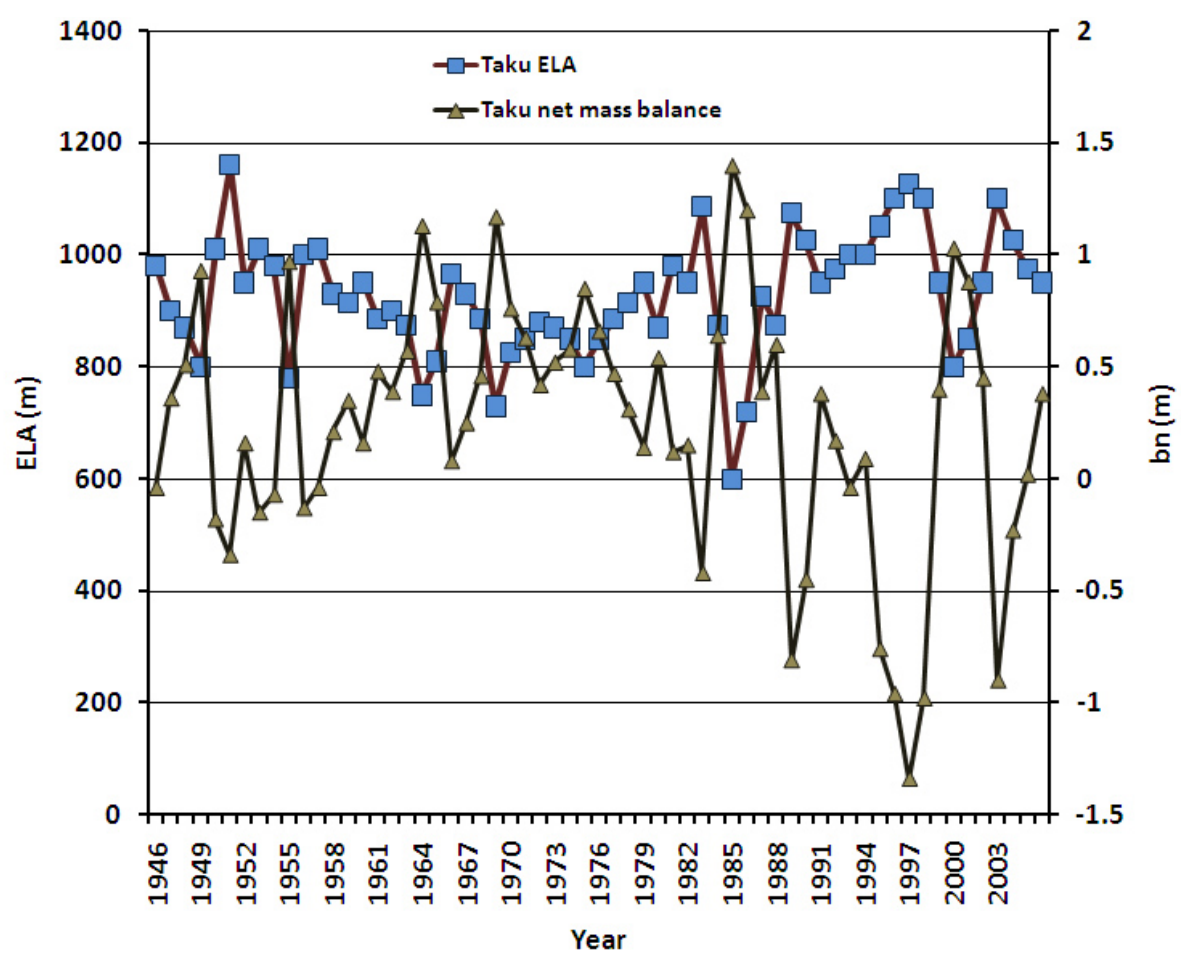

Fig. 4. ELA and annual balance of Taku Glacier 1946-2006.

\section{Results}

\subsection{Mass balance}

The annual balance record shows a markedly positive trend from 1946-1988 period. The mean annual balance for the 42-year period is $0.42 \mathrm{~m} \mathrm{a}^{-1}$, representing a total thickening of $17.5 \mathrm{~m}$ w.e., $20 \mathrm{~m}$ in total ice thickness (Fig. 3). The ELA is compared to net mass balance (bn) in Fig. 4. The average ELA was $900 \mathrm{~m}$ from 1946-1988 and $1000 \mathrm{~m}$ from 1989-2006. From 1989-2006 mass balance changed significantly and has been slightly negative averaging $-0.14 \mathrm{~m} \mathrm{a}^{-1}$, 


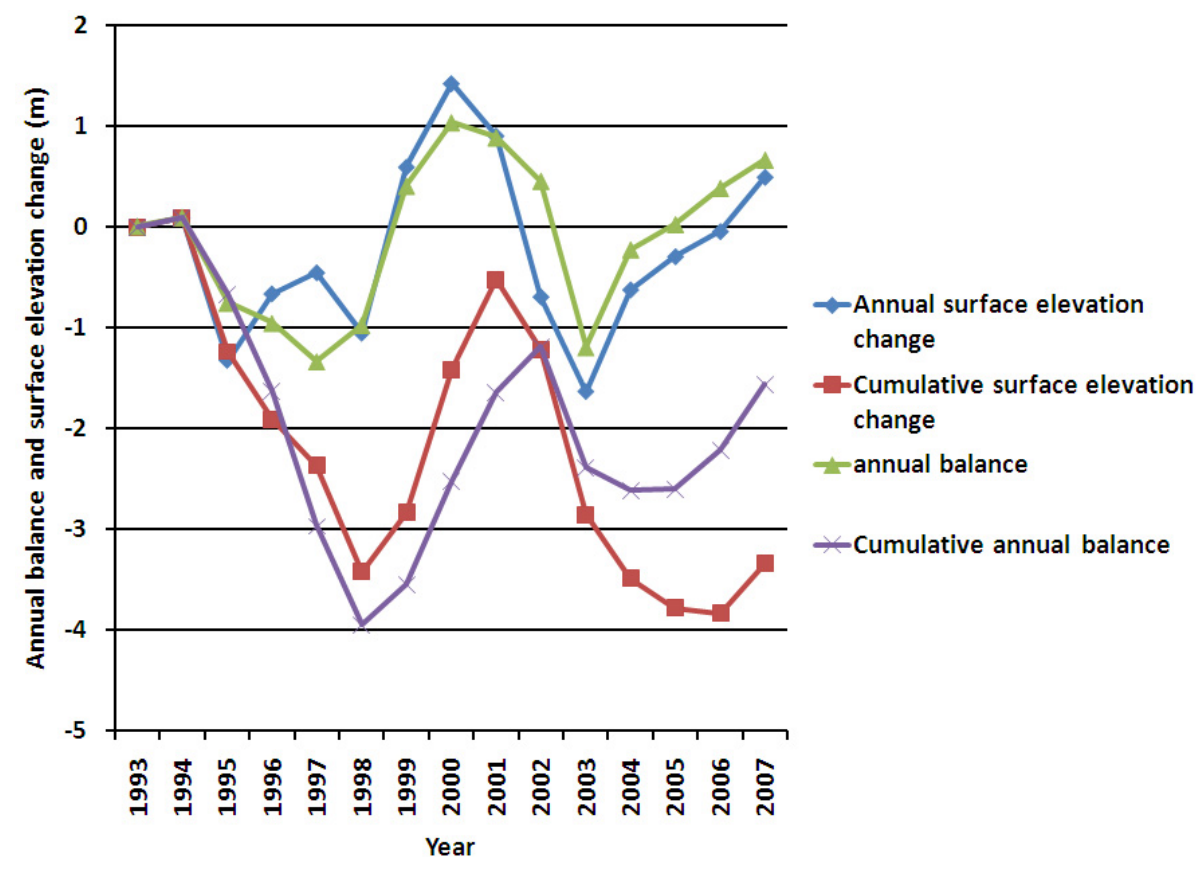

Fig. 5. Annual mass balance of the Taku Glacier 1994-2006, and the mean change in glacier surface elevation at Profile IV stations.

a $2.7 \mathrm{~m}$ of water equivalent loss, or $3.0 \mathrm{~m}$ of glacier thickness change. This represents a total period change of $17 \mathrm{~m}$. Observations along a profile surveyed in 1952 and 1993 indicated surface elevation changes ranged from $10-15 \mathrm{~m}$ in the upper accumulation zone of the Taku Glacier from 1952-1998 and 20-30 in the vicinity of Profile IV (Welsch and Lang, 1998). For the period 1993 to 2006, correlation between the average surface elevation change of a Profile IV across the Taku Glacier and net mass balance is 0.77 (95\% significance) (Fig. 5). A comparison of cumulative surface height change along Profile IV from 1993-2006 and cumulative surface balance yield $-3.5 \mathrm{~m}$ w.e. and $-2.6 \mathrm{~m}$ w.e. respectively. The difficulty in using height changes is the impact of glacier dynamics. In this case the consistency of the velocity over the last 50 years would suggest that glacier dynamics changes would not be impacting surface elevation substantially. This region of the glacier has a very limited vertical velocity vector. The next task in this research program is to determine the height changes at survey locations along additional profiles over an extended period, to determine the utility of the surface level change surveys for mass balance assessment at other locations on the glacier.

The final product for mass balance is a map of the distribution of mass balance across the glacier. This map as used to determine the mean annual surface flux for the glacier region above Profile IV, summing the product of the area observed between each $0.25 \mathrm{~m}$ mass balance increment and the annual balance for that increment. The mean surface flux accumulating above Profile IV for the 1950-2006 period was calculated to be $5.54 \times 10^{8} \mathrm{~m}^{3} \mathrm{a}^{-1}$.

\subsection{Transverse velocity profiles}

Surface velocity has been constant over a 50-year period on the Taku Glacier at Profile IV (Fig. 6) (Miller, 1963; Dallenbach and Welsch, 1993; Lang, 1997 and McGee, 2000). Measurements have focused primarily on summer field measurement of velocity. From 1950-1992 Profile IV was established in the same general location, though there was no means to ascertain that the stakes were positioned identically. In 1993, the profile was standardized at its present location and configuration. In Fig. 6 the mean velocity for the center section of the glacier, from Flag 10 through Flag 24, is noted for all published surveys. The maximum is $0.58 \mathrm{~m} \mathrm{day}^{-1}$ and the minimum $0.51 \mathrm{~m} \mathrm{day}^{-1}$, other than 1950 the maximum is $0.54 \mathrm{~m} \mathrm{day}^{-1}$. The velocity profile for the glacier in individual years is nearly identical (Fig. 7). This illustrates that at specific stake locations reoccupied each summer along Profile IV there is remarkable uniformity of flow from year to year (Fig. 7). Standard deviation ranges from $0.01-0.02 \mathrm{~m}$ day $^{-1}$ for each flag. This is always less than $5 \%$ of the total velocity.

Annual velocity shows no significant variations based on year round measurement of the movement of the top of a glacier borehole and the associated semi-permanent camp from 1950-1953 along Profile IV (Miller, 1963). Movement of a meteorologic station instrument that endured from 1997 to 1998 on Profile IV provided a second measure of mean annual velocity, $0.60 \mathrm{~m}^{\text {day }}{ }^{-1}$ versus mean observed summer velocity for this same location of $0.61 \mathrm{~m} \mathrm{day}^{-1}$. A magnet was buried in the glacier in July 2003 and then checked 


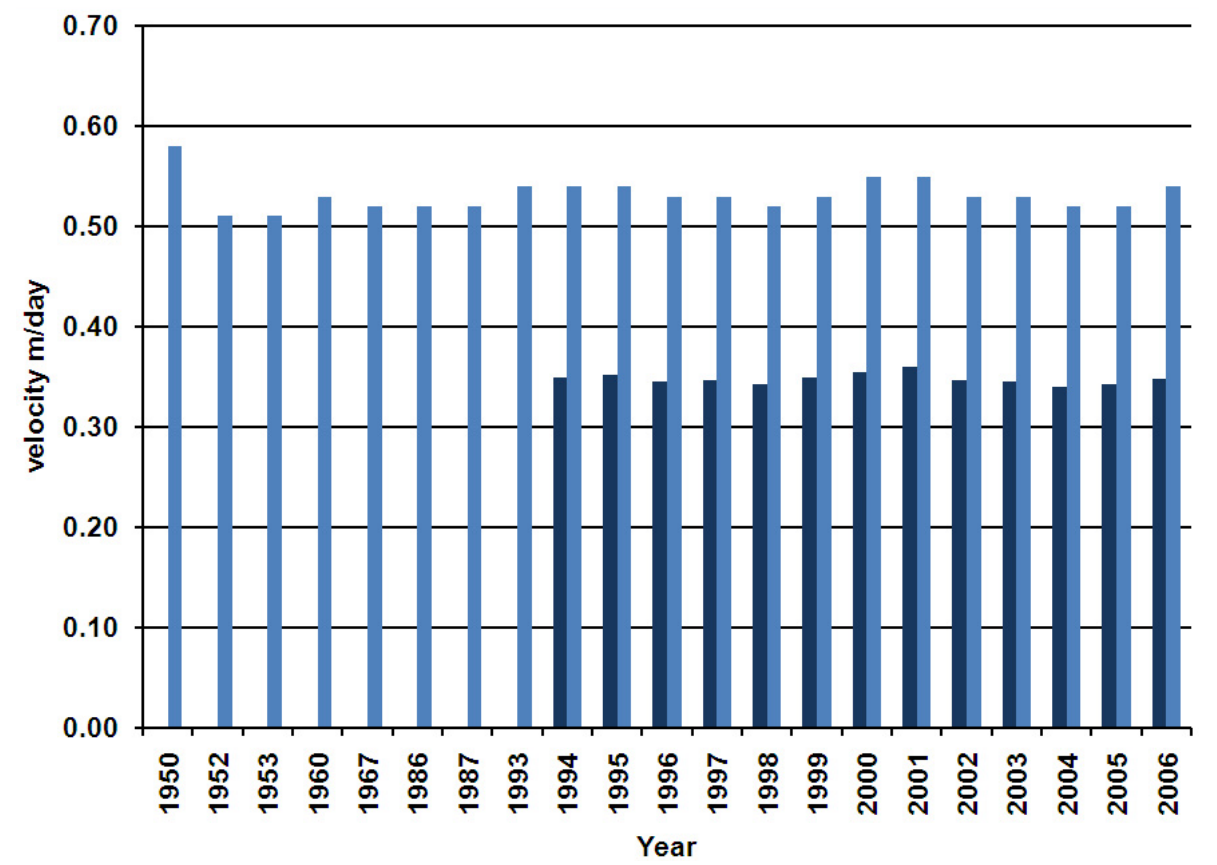

Fig. 6. The average velocity for Profile IV for the entire line from 1994-2006, and the average velocity for the center section of Profile IV upper line (between stations 10 and 24) for selected years from 1950-2006.

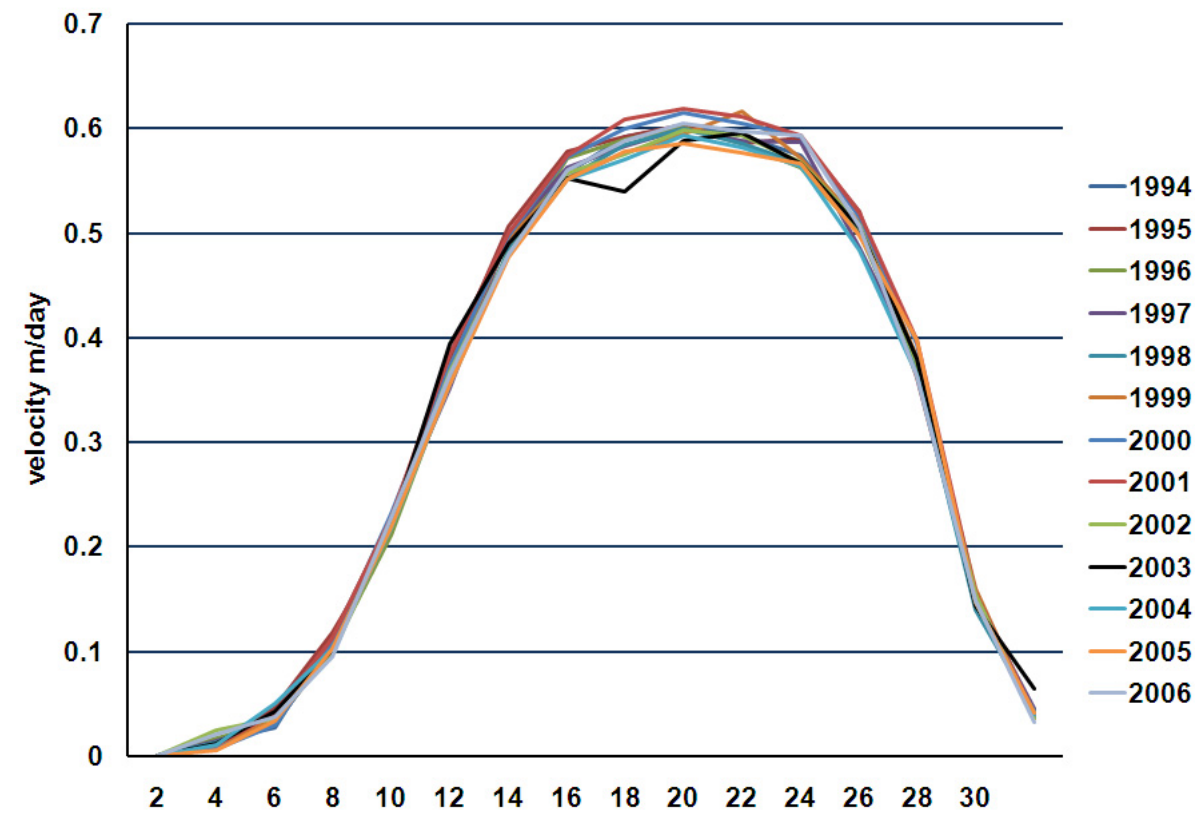

Fig. 7. Observed surface velocity $\left(\mathrm{m}^{\mathrm{day}}{ }^{-1}\right)$ along Taku Glacier Profile IV Upper Line. The lack of significant change is evident.

in July 2004 to identify annual glacier velocity at Profile IV. The annual velocity was $0.587 \mathrm{~m} \mathrm{day}^{-1}$ and the summer velocity was $0.588 \mathrm{~m} \mathrm{day}^{-1}$.

Many temperate glaciers have a substantial component of glacier sliding that depends on bed hydrology, hence displaying seasonal variations. Taku Glacier, however, has excep- tionally thick ice, and a low basal gradient. The flow law for internal deformation suggests that negligible basal sliding is taking place in the accumulation zone (Nolan et al., 1995). The lack of seasonal velocity changes noted in this study and the remarkable uniformity in velocity suggest that sliding is a minor part of the glacier velocity at Profile IV. It is unlikely 


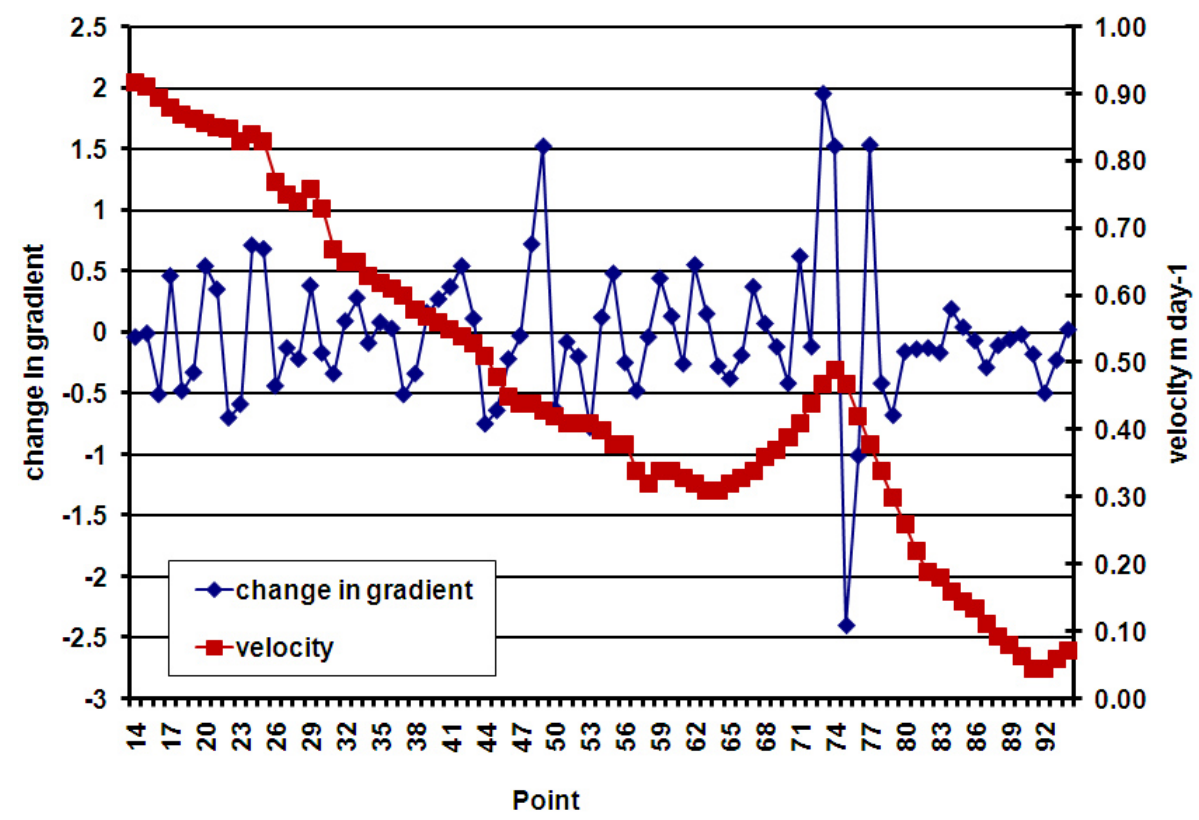

Fig. 8. Comparison of the change in surface gradient and velocity along a longitudinal profile of Taku Glacier, Alaska. Profile IV is at station number 38, note line. Stations are $0.5 \mathrm{~km}$ apart. Profile IV is in the midst of a region with steady glacier velocity increases and a limited gradient change. Surface gradients are in degrees a negative gradient represents a steepening gradient a positive gradient change a shallowing gradient.

that a glacier of this size would slow down each fall or winter, and then accelerate to exactly the same speed the following summer.

\subsection{Longitudinal profile}

The variation in velocity along a longitudinal profile extending from Goat Ridge at $800 \mathrm{~m}$ elevation, $20 \mathrm{~km}$ from the terminus, up the main trunk of the glacier, along the Matthes Branch, to the ice divide is shown in Fig. 8. This variation indicates generally increasing velocity with distance down glacier from the divide at point 94 to point 13 just below the ELA. One notable deviation from the pattern of steady velocity increase is where the glacier steepens as Taku Glacier leaves the high plateau and enters the narrower valley of the Matthes Branch, causing a rapid acceleration from point 81 to point 76 . The glacier then slows under longitudinal compression as the surface slope declines from point 76 to point 66 . A steady increase in surface velocity then ensues to point 13 . The velocity along this longitudinal profile has been repeated in 2001 and 2004. The maximum velocity change was $0.02 \mathrm{~m} \mathrm{day}^{-1}$, and the mean change for each point was $0.004 \mathrm{~m} \mathrm{day}^{-1}$. Again, this indicates the annual and seasonal consistency of velocity along the glacier and the equilibrium nature of its flow (Fig. 8). Profile IV is in the middle of a region of steady velocity increase (Fig. 8).

\subsection{Glacier thickness}

The greatest thickness of the Taku Glacier was noted to be $1477 \mathrm{~m}$ at Goat Ridge, $22 \mathrm{~km}$ above the terminus (Nolan et al., 1995). The centerline depth of the glacier is greater than $1400 \mathrm{~m}$ at Profile IV (Fig. 9). The glacier thickness exceeds $1000 \mathrm{~m}$ for a width of approximately $2000 \mathrm{~m}$ in the center of the glacier. This section of the glacier coincides with the region with velocities in excess of $0.5 \mathrm{~m} \mathrm{day}^{-1}$. The minimum glacier bottom elevation at Profile IV is approximately $-350 \mathrm{~m}$. The transverse bed profile at Profile IV indicates benches on both the east and west sides of the glacier. The bench on the east side is an extension of the North Basin that is at the base of Taku B and just north of Camp 10. The bench on the west side lacks a clear surface topographic expression. The results on Profile IV match closely the results of Nolan et al. (1995), with a maximum depth of $1450 \mathrm{~m}$ in this study versus $1400 \mathrm{~m}$, certainly equivalent within the error limits.

\section{Calculation of volume flux}

With direct measurement of surface velocity, ice thickness and width for each increment of glacier width on the profiles, the only unknown in determining volume flux is determination of depth average velocity. Several points led Nolan et al. (1995) to conclude that basal sliding is minimal, most importantly the calculation of basal shear stress as $125 \mathrm{kPa}$. We determined basal shear stress to be $120-180 \mathrm{kPa}$ along 


\section{Profile IV}

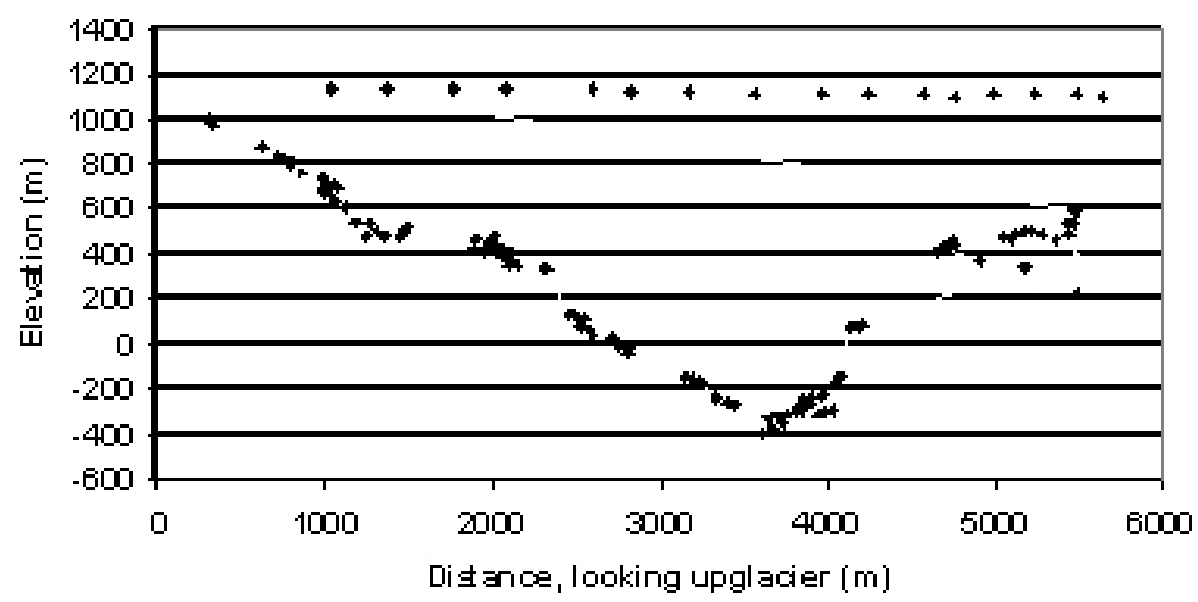

Fig. 9. Surface elevation of stations along Profile IV and seismically determined bottom topography along the profile, Taku Glacier, Alaska.

Profile IV. These values are beyond that at which substantial basal sliding would be anticipated. In addition, the consistency in velocity each summer and in annual velocity indicates that there is negligible seasonal fluctuation in velocity in the vicinity of Profile IV. Seasonal fluctuations are generally the result of changes in sliding.

To determine depth average velocity $\left(U_{d}\right)$ we have applied the Eq. (1)(van der Veen, 1999; Nick et al., 2007), using values from the center of the glacier.

$U_{d}=\frac{2 A H}{n+2} S_{d}^{n}$

where $A=4.6 \times 10^{-10} \mathrm{kpa}^{-3} \mathrm{day}^{-1}$ is the rate factor (Paterson, 1981), $n=3$ is the flow-law exponent, $H$ is the measured ice thickness $(1400 \mathrm{~m})$ and $S_{d}$ the basal shear stress noted above (125-180 kpa)(or basal drag). Plugging these values into Eq. (1) gives

$$
\begin{aligned}
U_{d} & =(2)\left(4.6 \times 10^{-10} \mathrm{kpa}^{-3} \mathrm{day}^{-1}\right)(1400) / 5 \times\left(120^{3}\right) \\
& =0.45 \mathrm{~m} \mathrm{day}^{-1}
\end{aligned}
$$

The lower value for basal shear stress is used at the suggestion of van der Veen (1999) since part of the driving stress is likely balanced by lateral drag. We then use the calculated value of $U_{d}$ to calculate $U_{s}$ from Eq. (3) (van der Veen, 1999):

Plugging the calculated $U_{d}$ velocity into Eq. (3) gives the surface velocity in Eq. (4)

$U_{s}=\frac{n+2}{n+1} U_{d}=1.25 U_{d}$

$U_{s}=0.56 \mathrm{~m} \mathrm{day}^{-1} / 1.25=0.45 \mathrm{~m} \mathrm{day}^{-1}$

$\mathrm{U}_{s}$ of $0.56 \mathrm{~m} \mathrm{day}^{-1}$ is an excellent agreement with the observed surface velocity of $U_{s}=0.6 \mathrm{~m} \mathrm{day}^{-1}$. This suggests that it is reasonable to use Eq. (3) to determine $U_{d}$ for each increment of glacier width.

The mean $U_{s}$ velocity between each two survey flags is used to represent the average $U_{s}$ for that width increment of the glacier. The mean depth for that width increment from the seismic profile is then determined. The product of the width of the increment and depth of the increment provide the mean cross sectional area. The mean $U_{s}$ for each increment is converted to a mean $U_{d}$ using Eq. (3).

The volume flux was determined separately for parallel survey lines along Profiles IV (upper line and lower line). For Profile IV, $29 \mathrm{~km}$ above the terminus, the expected volume flux, based on surface flux observations, was $5.50 \times 10^{8} \mathrm{~m}^{3} \mathrm{a}^{-1}( \pm 10 \%)$, the volume flux range was 5.00$5.47 \times 10^{8} \mathrm{~m}^{3} \mathrm{a}^{-1}$, with a mean of $5.25 \times 10^{8} \mathrm{~m}^{3} \mathrm{a}^{-1}$ for the upper line and $5.27 \times 10^{8} \mathrm{~m}^{3} \mathrm{a}^{-1}$ for the lower line (Table 1). This indicates a slightly positive balance and glacier thickening above Profile IV for the 1950-2006 period, which is corroborated by field observations (Welsch and Lang, 1998) and laser altimetry (Arendt, 2006; Larsen et al., 2007). The thickness change observations are in the range of expected values for the observed positive surface mass balance, the same conclusion that Nolan et al. (1995) reached. The calculated volume flux is based on the 1950-2006 average mass balance profile for the glacier and not for a given year. The surface flux during recent negative balance years would obviously give a lower surface flux value and in fact the surface elevation in the vicinity of Profile IV has not been increasing since 1993. 
Table 1. The calculated volume flux at Profile IV. Volume flux is in $\mathrm{m}^{3} \mathrm{a}^{-1}$. Annual values are followed by a comparison of the mean volume flux, mean observed surface flux and the difference between them. The difference in this case is a positive surface flux. The volume flux is determined from annual measurements. The surface flux is the mean for the 1946-2004 period.

\begin{tabular}{lcccccccccc}
\hline & 1996 & 1997 & 1998 & 1999 & 2000 & 2001 & 2004 & Mean & Surface & Difference \\
\hline 4LL & 5.25 & 5.34 & 5.07 & 5.38 & 5.42 & 5.41 & 5.20 & 5.27 & 5.5 & 0.20 \\
4UL & 5.33 & 5.22 & 5.19 & 5.23 & 5.33 & 5.39 & 5.17 & 5.25 & 5.5 & 0.23 \\
\hline
\end{tabular}

\section{Conclusions}

The results indicate that Taku Glacier has had an equilibrium flow, with no significant annual velocity changes in the last 50 years. Furthermore, although seasonal variations had been expected (Miller, 1963), observations of velocity throughout the year indicate no seasonal variations, probably due to high basal shear stress which inhibits sliding. The surface mass balance accumulating above Profile IV in the last half century is in excess of the volume flux through the profile. The result, supported by both survey results of JIRP and laser altimetry (Arendt et al., 2002; Larsen et al., 2007), is glacier thickening. The sustained thickening, positive balance, and consistent flux of the 1946-1988 period suggested that the glacier terminus would continue to advance (Pelto and Miller, 1990). From 1988-2005 the mass balance has been slightly negative, and the glacier has thinned slightly (Fig. 3) though the volume flux at Profile IV has not declined appreciably. The significant change in glacier mass balance beginning in 1988 is expected to influence the glacier velocity, volume flux and eventually the terminus, if it is sustained for another 20+ years. A reduced mass balance, along with the proglacial delta and expanding front of the glacier noted by Post and Motyka (1995), would lead to a reduction in the advance rate. The glacier velocity did not change appreciably as the glacier thickened by $10-20 \mathrm{~m}$ at Profile IV and it is expected that it would take a thinning of more than this to substantially alter glacier velocity.

Acknowledgements. This paper has benefitted from the comments and long term commitment to research on the Taku Glacier by Roman Motyka, and Keith Echelmeyer. The Juneau Icefield Research Program has provided the logistical support for the ongoing mass balance and survey studies, this support was coordinated by the indefatigable Joan Miller for 50 years.

Edited by: A. Kääb

\section{References}

Arendt, A. A.: Volume changes of Alaska glaciers: contributions to rising sea level and links to climate change, $\mathrm{Ph} . \mathrm{D}$ dissertation, University of Alaska, Fairbanks, 2006.

Arendt, A. A., Echelmeyer, K. A., Harrison, W. D., Lingle, C. S., and Valentine, V. B.: Rapid wastage of Alaskan glaciers and their contribution to rising sea level, Science, 297(5880), 382-385, 2002.

Daellenbach, K. and Welsch, W.: Determination of surface velocities, strain rates, and mass flow rates on the Taku Glacier, Juneau Icefield, Alaska, Zeitschrift für Gletscherkunde und Glazialgeologie, Band 26, Heft 2, 169-177, 1993.

Dobrin, M. B.: Introduction to Geophysical Prospecting, 3rd Edition, McGraw-Hill, New York, 201-254, 1960.

Dyugerov, M. B. and Meier, M. F.: Year to year fluctuations of global mass balance of small glaciers and their contributions to sea level, Arctic Alpine Res., 29, 392-402, 1997.

Lang, M.: Geodetic Activities of the 1997 Juneau Icefield Research Program Field Season, Open File Survey Report, Juneau Icefield Research Program, Foundation for Glacier and Environmental Research, Moscow, Idaho, 1997.

Larsen, C. F., Motyka, R. J., Arendt, A. A., Echelmeyer, K. A., and Geissler, P. E.: Glacier changes in southeast Alaska and northern British Columbia and contribution to sea level rise, J. Geophys. Res., 112, F01007, doi:10.1029/2006JF000586, 2007.

March, R. S. and Trabant, D. C.: Mass balance, meteorological, ice motion, surface altitude, and runoff data at Gulkana Glacier, Alaska, 1992 balance year, US Geological Survey Water-Resources Investigations Report 95-4277, 1996.

Mayo, L. R., Trabant, D. C., and March, R. S.: A 30-Year Record of Surface Mass Balance (1966-95), and Motion and Surface Altitude (1975-95) at Wolverine Glacier, Alaska, US Geological Survey Open-File Report 2004-1069, 2004.

McGee, S.: Juneau Icefield GPS Movement Profile Coordinates, JIRP Open File Survey Report, Juneau Icefield Research Program, Foundation for Glacier and Environmental Research, Moscow, Idaho, 2000.

Miller, M. M.: Taku Glacier Evaluation Report. State of Alaska, Dept. of Highways and Bureau of Public Roads, US Dept. of Commerce, 1963.

Miller, M. M. and Pelto, M.: Mass balance measurements on the Lemon Creek Glacier, Juneau Icefield, AK 1953-1998, Geografiska Annaler, 81A, 671-681, 1999.

Motyka, R. and Post, A.: Taku Glacier influence of sedimentation, accumulation to total area ratio and channel geometry on the advance of a fjord-type glacier, in: Proceedings of the Third Glacier Bay Symposium, edited by: Engstrom, D. R., National Park Service, Anchorage AK, 38-45, 1995.

Motyka, R. and Beget, J. E.: Taku Glacier, Southeast Alaska, U. S. A.: Late Holocene history of a tidewater glacier, Arctic Alpine Res., 28(1), 42-51, 1996.

Nick, F. M., van der Veen, C. J., and Oerlemans, J.: Controls on advance of tidewater glaciers: Results from numerical modeling applied to Columbia Glacier, J. Geophys. Res., 112, F03S24, 
doi:10.1029/2006JF000551, 2007.

Nolan, M., Echelmeyer, K., Motyka, R., and Trabant, D.: Ice thickness measurements of Taku Glacier, Alaska, USA, and their relevance to its recent behavior, J. Glaciol., 41(139), 541-552, 1995.

Nye, J. F.: The flow of a glacier in a valley of rectangular, elliptic or parabolic cross section, J. Glaciol., 5(41) 661-690, 1965.

Paterson, W. S. B.: The Physics of Glaciers, 2nd ed., Pergamon Press, Oxford.

Pelto, M. and Miller, M. M.: Mass Balance of the Taku Glacier, Alaska from 1946 to 1986, Northwest Sci., 64(3), 121-130, 1990.

Post, A. and Motyka, R.: Taku and Le Conte Glaciers, Alaska: Calving speed control of late-Holocene asynchrounous advances and retreats, Phys. Geogr., 16, 59-82, 1995.

Ramage, J. M., Isacks, B. L., and Miller, M. M.: Radar Glacier zones in southeast Alaska, U.S.A.: field and satellite observations, J. Glaciol., 46(153), 287-296, 2000.
Sprenke, K. F., Miller, M. M., McDonald, F., Haagen, C., Adema, G., Kelly, M., Barbour, S., and Caceres, B.: Geophysical investigation of the Taku-Llewellyn Divide: a NASA Earth Systems Field Research Project, Juneau Icefield, Alaska, Juneau Icefield Research Program Geophysics Open File Report 97-1, (Moscow, Idaho: Glaciological and Arctic Science Institute, University of Idaho), 1997.

Van der Veen, C. J.: Fundamentals of Glacier Dynamics, Lisse, A. A. Balkema, 462 pp., 1999.

Welsch, W., Lang, M., and Miller, M. M.: Geodetic Activites Juneau Icefield, Alaska 1981-1996, Schriftenreihe des Studiengangs Vermessungskunde, Universität der Bundeswehr, Heft 50, 1996.

Welsch, W. and Lang, M.: Geodetic Activities of the 1998 Juneau Icefield Research Program Field Season, Open File Survey Report, Juneau Icefield Research Program, Foundation for Glacier and Environmental Research, Moscow, Idaho, 81 pp., 1998. 